\title{
Por fim... aspectos da história do Contestado pelo jornalismo
}

\author{
Karina Janz Woitowicz
}

\section{SciELO Books / SciELO Livros / SciELO Libros}

WOITOWICZ, KJ. Por fim... aspectos da história do Contestado pelo jornalismo. In: Imagem contestada: a guerra do contestado pela escrita do diário da tarde (1912-1916) [online]. Ponta Grossa: Editora UEPG, 2015, pp. 305-322. ISBN 978-85-7798-212-7. Available from SciELO Books $<\underline{\text { http://books.scielo.org }>\text {. }}$

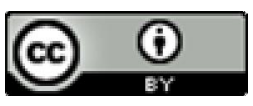

All the contents of this work, except where otherwise noted, is licensed under a Creative Commons Attribution 4.0 International license.

Todo o conteúdo deste trabalho, exceto quando houver ressalva, é publicado sob a licença Creative Commons Atribição 4.0.

Todo el contenido de esta obra, excepto donde se indique lo contrario, está bajo licencia de la licencia Creative Commons Reconocimento 4.0. 


\title{
Por fim... aspectos da história do Contestado pelo jornalismo
}

\author{
Ah, quem escreverá a história do que \\ poderia ter sido? Será essa, se alguém a \\ escrever, a verdadeira história \\ da humanidade. \\ Fernando Pessoa
}

O percurso pelas falas do Diário da Tarde permitiria, a partir das temáticas e problemáticas propostas, reconduzir a leitura para outras possibilidades de análise dos mesmos discursos, desvendar outros sentidos e sugerir ângulos e olhares diferentes, demonstrando assim que o trabalho de investigação não está, absolutamente, terminado. Mas isto implicaria ignorar uma unidade reflexiva que faz que as abordagens específicas da pesquisa se encaixem, fazendo sentido e organizando preocupações comuns sobre o papel do jornalismo na construção da realidade sócio-histórica do caso Contestado.

Por isso, atentaremos não para o que poderia ser feito - no sentido de justificar possíveis lacunas, imprecisões e mesmo falhas - mas para o que foi efetivamente desenvolvido neste livro, acentuando discussões que, embora possam não estar pontualmente trabalhadas e referidas em cada capítulo, ainda assim constituem o pano de fundo das observações feitas na interpretação e na confrontação dos textos jornalísticos. Estamos nos referindo, especificamente, àquilo que o jornal constrói ao dizer - dando, ponderando e articulando vozes da sociedade -, de modo a demarcar um campo de atuação e interferência na realidade e, portanto, na própria escrita da história.

Como é necessário organizar um conjunto de observações reflexivas feitas ao longo da pesquisa, é oportuno considerar que o estudo proporcionou um reaprender não menos crítico sobre o papel que o dizer/fazer 
jornalístico adquire nas práticas que passam a integrar a memória coletiva e a história de um povo ou região. Um aprofundamento sobre uma simples, mas importante constatação: fazer jornal é fazer história. Trata-se de uma prática discursiva que se poderia comparar à magia exercida pelos contadores de história oral, antes do imperioso advento das mídias eletrônicas e de alcance massivo. E que não é uma magia da repetição, como se espera de certos efeitos subliminares da publicidade. Mas uma magia que atrai pelo jeito de informar, num mundo caótico que precisa de uma ordem, escala de valores e seletividade interpretativa. Pensar nesse efeito da prática discursiva pode situar melhor o "lugar de fala" ocupado pelo jornal nas primeiras décadas de século $\mathrm{XX}$ ou, mais especificamente, o Diário da Tarde na Guerra do Contestado.

Esse espaço ocupado pelo jornal se efetua porque a história não se limita a ser a "ciência dos indivíduos no tempo", como apregoa uma escolar definição da historiografia oficial brasileira. A história ganha forma e significado nos conflitos de sentido que os diversos meios informativos levam ao seu público alvo. Nos sentidos que se chocam e vão formar as interpretações variadas existentes sobre os mesmos fatos históricos...

Inicialmente, procuramos conhecer um pouco o modo particular de "dizer" a vida social desempenhado pelo jornalismo nas primeiras décadas do século passado, compreendendo o sentido e a participação do jornal no contexto da sociedade paranaense. Partindo das considerações gerais sobre o jornalismo para chegar às especificidades do Diário da Tarde - como se constitui enquanto espaço público, promovendo discussões sobre os aspectos educativos, sociais e culturais e, desse modo, constrói o cotidiano da cidade -, buscou-se identificar um amplo cenário no qual o jornal atua, percebendo as relações de "intromissão" entre a imprensa e a sociedade paranaense no período da Guerra do Contestado.

Percorrendo este caminho, o que pudemos constatar sobre a atuação do periódico na discursivização dos acontecimentos e das questões que envolvem a revolta sertaneja? Tratamos, basicamente, de considerar os discursos sobre o Contestado pelo viés da produção de sentido resultante das falas específicas do jornal. Assim, a complexidade constitutiva do trabalho com as notícias - diluída na articulação de vozes que disputam sentidos no espaço do jornal, na mediação dos fatos por uma angulação determinada e no papel do jornal na construção dos acontecimentos - nos ofereceu elementos para compreender a presença, a participação e a interferência do 
jornal na instituição de significados e o modo como são compreendidos e processados pela sociedade.

É importante destacar ainda que a pesquisa não procurou fenômenos objetivos, mas, antes, efeitos e representações desses fenômenos no caso Contestado. Em dias sucessivos vai aparecendo uma série de fatos ou acontecimentos diversos que fazem parte do mesmo "clima de opinião" e, por isso mesmo, produzem determinados sentidos e não outros. Progressivamente, estes fatos vão constituindo um modo específico de tratamento dado ao caso, e configurando uma leitura determinada da realidade histórica.

Isto quer dizer que a relação dizer/fazer, tomada como princípio para a análise dos textos jornalísticos, manifesta-se em cada página do Diário da Tarde pelo modo como são tematizadas e tratadas as questões da realidade social, de modo a produzi-las como uma outra realidade que vem compor o mundo. Pudemos observar este processo pelo posicionamento do jornal em momentos específicos da Guerra, quando elabora um "lugar" para produzir sentido - seja fazendo prevalecer determinada angulação em meio às notícias, seja manifestando juízos e impressões, seja incitando o próprio desfecho dos acontecimentos - e, desse modo, atua no universo social cotidiano. Este "fazer", enquadrado em campo de referências características ao jornalismo da época e ao pensamento social (pre)dominante, foi capaz de informar não apenas os temas e as construções discursivas vigentes no período estudado, mas principalmente o modo como o periódico registra, produz e transforma as "estórias" testemunhadas pelas páginas impressas, dando materialidade às vivências e aos acontecimentos do presente.

Do mesmo modo que a busca de regularidades entre os sentidos e as formas de construir estes sentidos pautou esta pesquisa, também o contraste entre os textos que rompem ou questionam determinadas abordagens sustentadas pelas vozes da sociedade e pelos discursos jornalísticos mereceu destaque nos encaminhamentos da análise. Pois o próprio "fazer-se" da imprensa, colocando em jogo as contradições e os interesses que orientam a tomada de posição do jornal, representa um elemento de fundamental importância para a compreensão dos processos midiáticos que atuaram no período da revolta sertaneja.

Neste espaço que o jornal constrói para “dizer" a realidade, marcado por discursos variados e até mesmo opostos ao longo da guerra, também é interessante perceber como os principais atores envolvidos nas questões 
do Contestado são representados ou, ainda, representam-se. Produzindo e movimentando os sentidos do fanatismo, da criminalidade e da ignorância, de modo a elaborar uma caracterização generalizada do sertanejo, o jornal contribui para a formação de uma opinião praticamente consensual que circula entre uma leitura negativa ou condescendente do real. Do lado oposto, também cria uma determinada imagem das forças militares que permite "dizer" sua condição em meio a um projeto nacionalista; mais do que simplesmente assumir o apoio a estas forças, o jornal faz que a verdade dos fatos pertença a um dos lados, sendo ele mesmo o componente "julgador" deste processo.

Este tipo de construção discursiva, polarizada no tratamento de fatos e opiniões, repercute também em outras questões trabalhadas na sequência da pesquisa, quando a imprensa atua na produção de sentidos sobre a religiosidade, as questões sociais que envolvem o movimento, a disputa territorial, a versão predominante da Guerra construída pela imprensa, entre outras. Afinal, organizados a partir de temáticas pontuais, os textos analisados poderiam perfeitamente se encaixar em outros ângulos, para complementar, confrontar ou mesmo confirmar estas (ou ainda outras) abordagens.

Esta percepção - que não tem como finalidade apontar outras possíveis leituras, mas demonstrar que, entre os textos, há inúmeros pontos de (inter)relação - parece pertinente justamente por colocar em discussão as implicações do trabalho simbólico desenvolvido pelo jornalismo na conformação da realidade, na medida em que as falas do Diário da Tarde em torno de diversos assuntos constituem um campo maior de produção de sentido que incide na própria maneira como os fatos assumem existência pública no cotidiano da sociedade.

Neste ângulo, procuramos ver propriamente o trabalho de elaboração jornalística, entendendo que para compreender as narrativas é preciso analisar como são construídas, incluindo mecanismos discursivos que fazem ser construído um acontecimento de determinada maneira e não de outra, no sentido de manifestar uma singularidade que lhe é constitutiva.

Recuperando a noção de "lugar de fala" proposta por José Luiz Braga, podemos dizer que ao dar e ponderar espaço às vozes da sociedade, traduzindo posições e motivações, o jornal também fala sobre si mesmo. E, ao "dizer", demarca um "lugar" segundo o qual se constrói aquilo que entende, critica e polemiza em relação ao movimento sertanejo. Mesmo 
que o jornal recorte e reproduza falas de determinados segmentos sociais - o exército, a igreja, os grupos políticos e econômicos etc. - é preciso considerar a própria fala do jornal, ao realizar escolhas, emitir pontos de vista e apontar inimigos e aliados, como um modo particular de ação no universo social, capaz de organizar estas mesmas falas para fazê-las articular, negociar e fixar sentidos.

Assim, podemos concluir que a interlocução mantida entre o jornal e demais forças sociais que acompanharam e participaram dos acontecimentos e decisões vai elaborando o que chamaríamos hoje de "opinião pública", um trabalho simbólico constituído pela articulação de visões opostas e contraditórias que vai modelando percepções e sentidos em torno de determinados assuntos e leituras do real. Em se tratando do Contestado, constatamos que esta atuação foi ordenando percepções de mundo que, associadas ao modo como os eventos foram narrados, fizeram parte de um mesmo "consenso" discursivo que construiu a imagem do Contestado nas páginas do jornal.

É preciso lembrar também que verificamos nesta pesquisa o posicionamento do jornal ao envolver interesses políticos, defendendo e acusando grupos e personagens envolvidos no debate sobre o caso e legitimando, de maneira indireta, os compromissos editoriais do próprio periódico em pauta. Esta foi uma das maneiras pelas quais o jornal mostrou seu fazer, interferiu nos rumos do conflito e marcou sua posição na sociedade paranaense. Associada a uma série de outros ângulos e perspectivas de temática e de abordagem, estas práticas contribuem para delimitar o papel e o perfil do Diário da Tarde na discursivização da Guerra do Contestado.

Ao nos defrontarmos com os jornais, percebemos então que mais do que distribuir papéis e produzir representações específicas aos indivíduos e grupos relacionados à Guerra do Contestado, os textos mantinham irrestritas relações com o contexto em que atuavam e ajudavam a construir. Por isso, pareceu-nos indispensável o tratamento de questões relevantes ao cenário social da época, como a religiosidade (ou melhor, a crítica a um catolicismo "rústico", fundado no que o jornal define como ignorância e crendice), a luta pelo direito à terra (uma disputa de forças que tangencia a construção discursiva dos acontecimentos e é ocultada entre outros temas e assuntos do conflito), o sentido da Monarquia em oposição às insatisfações que coincidem com a República (uma leitura que manifesta mais uma concepção de mundo do que propriamente um projeto político, tratada com 
condenação pelo jornal), a influência do capital estrangeiro (um jogo de poderes que incide inegavelmente no tratamento de questões sociais) e a própria concepção de movimento social que se cria ao noticiar o Contestado, uma vez que os diversos temas mencionados dizem respeito à inserção da imprensa em um chão social marcado por expressivas contradições. Cada uma destas questões, ao ser pautada, tematizada e trabalhada pelo jornal a partir de enfoques e motivações específicas, constitui uma maneira particular de construção da realidade, trazendo à tona uma relação (nem sempre pacífica) entre os fatos e as estórias sobre estes mesmos fatos.

É por este viés que também pudemos encontrar inúmeras marcas de um discurso polêmico que se institui e é instituído pelo jornalismo em torno das questões políticas que envolvem a disputa territorial entre os dois estados - um assunto que chamou a atenção justamente pela intensa repercussão na imprensa, ao ponto de se poder dizer que o debate se constitui mais em relação à oposição Paraná/Santa Catarina do que nos próprios acontecimentos do Contestado. Buscando os diferentes modos de tratar e angular a questão - utilizando-se de argumentos favoráveis e contrários a determinadas decisões, estabelecendo um debate público na imprensa ou mesmo demarcando sua função como órgão de informação e opinião - o Diário da Tarde participa dos rumos da discussão e, por meio destas estratégias discursivas, permite o deslocamento e a reconfiguração de posições que seguem uma orientação editorial dada. Basta lembrar o trabalho de negar e afirmar, condenar e absolver, aceitar e questionar (questões, personagens e fatos) promovido pelo periódico, principalmente em se tratando dos discursos referentes à disputa territorial.

Pudemos encontrar, ao longo da pesquisa, uma série de questões que parecem comuns ao jornalismo praticado no início do século XX no Brasil - em termos de forma, conteúdo e modos de dizer - que renderam reflexões importantes sobre as implicações dos processos midiáticos na vida social. No entanto, nosso objetivo aqui é perceber e elucidar que jornal específico surge nesta análise quando o Diário da Tarde enuncia determinadas falas, toma certas posições e constrói modos de ver a realidade. Em outros termos, observar que ação é esta que o jornal paranaense desempenha ao articular conteúdos simbólicos, definindo e redefinindo, construindo e reconstruindo significados e maneiras de dizer/fazer as coisas.

Podemos dizer, a princípio, que a relação do jornal com a realidade cotidiana não é absolutamente definida pela "reprodução" dos fatos em 
notícias impressas... os fatos também "acontecem" porque foram escritos no Diário da Tarde, produzidos de um modo particular e segundo orientações distintas. Com a análise dos discursos mediáticos do Contestado, verificouse que o campo jornalístico paranaense acompanhou e, em boa medida, definiu os acontecimentos da Guerra do início ao fim. Assim, mesmo que se tenha adotado uma organização temática para analisar o tratamento das principais questões do conflito no periódico, a pesquisa não ignora uma evolução cronológica da Guerra que, associada ao contexto sóciohistórico, justifica determinadas posturas e angulações propostas pelo Diário da Tarde para dizer a realidade de acordo com a situação em pauta.

Isto permite considerar que, deste "início" a este "fim", não se pode simplesmente dizer que o jornal esteve a favor ou contra determinado setor político ou grupo social ou agiu em defesa do "povo", genericamente representado em suas páginas. Este percurso de quatro anos esteve marcado por conflitantes sentidos, que foram construídos em meio a falas e representações de modo a traçar redes de significados aceitas coletivamente como verdadeiras; ou seja, dizendo coisas diferentes, e de diferentes modos, o jornal vai construindo um "todo" que representa uma leitura - sua leitura - dos acontecimentos do Contestado.

Reunindo as temáticas trabalhadas na pesquisa, e tendo em vista o trabalho desenvolvido pelo jornal para ler e dizer o real, podemos nesta etapa das conclusões pensar o Contestado também em termos de um processo elaborado e assimilado dentro de um quadro de referências produzido pelo Diário da Tarde. Dentro deste enfoque, podemos perceber a inter-relação entre o contexto e o objeto, ou seja, entre os acontecimentos do Contestado e o modo como o jornal os tematiza e constrói. Ao anunciar o primeiro conflito, com incomparável dramaticidade, já se começa a demarcar um "lugar" para definir inimigos e aliados e narrar os acontecimentos segundo critérios específicos de abordagem e angulação. $\mathrm{O}$ rebaixamento de uma cultura "subalterna", própria do sertanejo, e o engrandecimento de qualidades como a bravura e a humanidade, que aparecem como exclusivas dos militares, vão assim forjando um clima próprio para a tematização dos conflitos.

Diante da ameaça de crescimento e fortalecimento de um movimento social de resistência impulsionado por adeptos de um líder messiânico, surgem as primeiras aclamações de aliança às forças oficiais, marcadas pelo estabelecimento da oposição nós/eles no discurso jornalístico, forjando 
uma imagem do sertanejo que se reafirma em cada novo episódio e circula - sempre de maneira negativa, conforme procuramos demonstrar - entre fanáticos, criminosos e vítimas. Ao lado dos militares, entretanto, cabem as homenagens e referências que beiram à mitologização, repercutindo de modo praticamente consensual o pensamento da época.

Outros elementos vão sendo acrescidos à disputa para mostrar que não se trata de uma luta polarizada entre um "nós" e um "eles", simplesmente; há também questões sociais bastante complexas que o jornal denuncia e oculta, sugere e silencia, movendo-se entre falas e situações e articulando variados pontos de vista para dizer suas verdades. Embora necessariamente referidos no periódico analisado em momentos pontuais do conflito sertanejo, estes assuntos não chegam a entrar na "agenda pública" de temas discutíveis com o devido destaque; contudo, pareceu-nos fundamental perceber que tais referências ao contexto da época representaram para esta análise argumentos importantes para melhor cercar o objeto de pesquisa e identificar possíveis implícitos e ocultamentos. Tratam-se de questões relacionadas ao direito à terra, à política de concessão de benefícios às empresas estrangeiras, aos interesses políticos que nortearam os acontecimentos do Contestado e outros aspectos nem sempre visíveis na superfície dos textos jornalísticos, obscurecidos em meio a discursos patrióticos e ataques aos opositores políticos.

Com a intensificação dos combates e o fortalecimento do movimento sertanejo, em 1914, começam a aparecer críticas pontuais ao modo como estavam sendo conduzidas as operações: muita violência e poucos resultados. Mesmo mantendo a linha de oficialidade que lhe é característica, o Diário da Tarde passa a cobrar medidas definitivas para o fim do conflito entre os "fanáticos" e as forças oficiais. Falhando em tentativas "pacíficas", chega-se a um momento, já em 1915, em que os apelos de piedade parecem cair no esquecimento. O jornal promove e comemora cada nova investida das forças, reativando uma espécie de memória da mitologia criada em torno dos feitos heróicos dos representantes da ordem.

Quando, enfim, restam apenas poucos focos de resistência, a guerra parece sair da pauta diária do jornal para dar espaço à disputa pelas terras contestadas que, até o momento, já haviam figurado como cenário de sangrentos combates. É a política estadual que orienta o rumo dos acontecimentos, com o aval mais ou menos evidente da imprensa, enquanto as varreduras policiais garantem o fim do movimento sertanejo. O Diário da 
Tarde vivencia de maneira tensa e intensa os acontecimentos do Contestado, traduzindo descontentamentos e revestindo sua opinião de um aspecto propriamente "público" ao articular falas conciliadoras, ataques discursivos e alianças variadas no cenário da imprensa da época.

Esta foi, resumidamente, a trajetória do Contestado no periódico paranaense. Ao longo da presente pesquisa, observamos que o espaço construído pelo Diário da Tarde para tratar os eventos em meio a vitórias, derrotas, novos redutos sertanejos e velhas disputas políticas é marcado por uma sequência de atos de dizer e desdizer ideias e posições, de modo a definir um papel e uma função particular no contexto da sociedade paranaense do período estudado.

A verificação deste percurso se dá pela própria tematização que o Diário da Tarde faz dos eventos ao longo do conflito. O modo como o periódico discute e silencia estes temas polêmicos mostra-nos que cada novo relato noticioso - marcado, inevitavelmente, por construções já dadas e legitimadas - promove também uma continuidade de significados que faz parte de uma "lógica" específica do jornal no tratamento das informações, determinada por um conjunto de posturas e alianças por ele definidas.

Esta "lógica" possibilitou constatar que a generalização de uma opinião favorável em relação ao combate aos sertanejos e os impasses polarizados entre as imprensas dos dois estados na definição dos direitos sobre os limites colocou os leitores diante de um tipo de consenso sobre o assunto que, de um modo genérico, foi a versão que ficou para a história. Facilitou, também, as manifestações e atitudes dos jornalistas, que se mostraram membros ativos na construção dos fatos ao se incluírem no próprio processo de "contar" a história. Em não raros momentos deparamos com expressões que manifestam explosões de dramaticidade ou afirmações de verdade, mostrando que os jornalistas assumiram um papel que ultrapassa a mera narração dos fatos: aproximaram-se dos participantes, comungaram com eles as emoções, sofreram diante das notícias de fracasso, temeram cada novo conflito, comemoraram as vitórias; e a diversidade desses estados de espírito projetaram-se, inevitavelmente, no produto de seu trabalho, que vem confirmar um tipo de leitura da imprensa da época ainda pouco preocupada em parecer distante ou imparcial (salvo eventuais afirmações editoriais).

Neste sentido, é importante lembrar que, quando nos referimos à noção de campo polêmico, estamos considerando algo que se manifesta 
nos níveis interno e externo do discurso. Por isso, observamos também certas configurações específicas do campo polêmico jornalístico - como a imprensa se mostra, dialoga com outros órgãos e oferece sua visão do jornalismo -, apreendendo as relações que estabelece com o campo polêmico geral da sociedade e das forças político-sociais que põe em cena em seu trabalho discursivo. Os ângulos e as posições que o jornal adota para discutir a profissão constituem uma importante referência para pensar a presença e atuação do campo mediático na produção do contexto sóciohistórico da época.

A partir destas considerações, foi possível perceber o papel do jornal no registro e na construção de fatos históricos enquanto uma das preocupações principais desta pesquisa. Entendendo que o jornal, ao narrar de tal maneira os acontecimentos da Guerra do Contestado, estabelece uma relação de constituição mútua entre o cotidiano e a história, consideramos o processo de escrita do Contestado nas falas do Diário da Tarde como resultado dos discursos que, enquanto acontecimentos, tornam-se situações efetivamente integrantes da realidade histórica e social do mundo. Dito de outro modo, se os fatos "não são evidentes por si mesmos", como sugere Paul Veyne, ao jornal cabe a função de torná-los legíveis e garantir-lhes existência pública, preenchendo cada página de fatos, opiniões e sentidos latentes.

Por todos estes motivos, que evidenciam as implicações da prática jornalística na vida, na história e no imaginário da sociedade, é que podemos considerar o jornal como produtor de um discurso social. Um discurso, certamente, feito de "pedaços" do contexto social, político e econômico, mas que acima de tudo existe porque produzido pelo jornal, por um modo particular de dizer - e, portanto, fazer - a realidade.

Referidas estas abordagens principais trabalhadas na pesquisa, resta-nos voltar o olhar para os processos mediáticos que são elaborados pelo jornal, ou seja, como este se constrói pelos textos que produz. Em meio a vozes variadas e opostas que constituem o "campo polêmico" da imprensa, o Diário da Tarde expressa sua voz construindo o próprio campo em que estas vozes são ditas; manifesta, assim, sua participação e inserção em um cenário de produção e constituição de sentidos.

Mas, afinal, que voz é esta que o jornal lança à sociedade e "pede" para ser ouvida? Trata-se de uma voz, ou fala, que ecoa de um "lugar" que se move nos eventos e na disputa de forças sociais e angula as abordagens 
que vai dando aos acontecimentos. Uma voz que diz a própria atuação do jornal (conforme procuramos mostrar nos momentos em que o jornal assume uma causa, justifica opiniões e posições ou discute as funções e o trabalho da imprensa e do jornalista) marcada por um modo singular de compreender (e verbalizar) as relações entre os acontecimentos do Contestado e a vida cotidiana no Paraná. Enfim, um "lugar" que permite o convívio entre perspectivas consensuais ou contraditórias e vai tecendo representações específicas para a condição sertaneja, o discurso nacionalista, a religiosidade, a disputa territorial e uma série de outras temáticas que nele ganham visibilidade (ou são silenciadas). As pistas para a identificação deste "lugar" estão nos próprios textos, que além das interferências de saberes e poderes diversos, são revestidos de uma singularidade enunciativa que lhes recorta e institui a materialidade histórica.

Sobre o modo singular de produzir os acontecimentos e dialogar com o público, observamos que o Diário da Tarde é marcado por um certo tom de "oficialidade" que angula os fatos coerentemente em uma mesma direção. Ainda que em determinados momentos procure negar tal perspectiva, mostrando-se um veículo "imparcial" e "isento" de informação, o tratamento elogioso aos representantes do poder e os atores que figuram como fontes do periódico confirmam que, no transcorrer da construção midiática e histórica do Contestado, nem todas as vozes foram autorizadas a emitir opinião com a mesma intensidade, e nem produziram eco do modo como poderiam... São os militares, os representantes da Igreja Católica, os grupos empresariais e os políticos que falam sobre o Contestado e definem seus rumos; é o jornal que "escreve" estas vozes e faz valer sua voz. Ao povo, sobram notas na seção de reclamações e comentários esparsos no jornal.

Não queremos dizer, com isso, que o papel do periódico se limita a reproduzir as falas hegemônicas que atuam na sociedade paranaense no período estudado. Consideramos apenas que este caráter de oficialidade constitui uma das características do Diário da Tarde em sua construção das chamadas "forças da ordem", em que a abordagem jornalística adotada é reveladora de um perfil editorial de cumplicidade ao poder instituído. Esse tratamento, ao ganhar as páginas dos jornais em momentos específicos do conflito armado ou ser construído pelo periódico para manter um mesmo cenário de opinião, incide sobre a forma como a história é narrada e compreendida pela sociedade. 
Não nos faltam momentos em que é possível perceber esta oficialidade como constitutiva da prática jornalística do Diário da Tarde. Basta lembrar da presença e da credibilidade sugerida pelos depoimentos de figuras militares e líderes políticos, que aparecem no jornal como vozes da "verdade" dos fatos, apresentando posicionamentos e opiniões praticamente inquestionáveis. Por meio do trabalho do jornalista, de telegramas de autoridades e entrevistas com lideranças das forças armadas ou "testemunhas oculares" dos acontecimentos do Contestado a imprensa paranaense constrói um espaço simbólico específico para testemunhar e agir sobre os acontecimentos, utilizando-se do testemunho de figuras públicas que se tornam as fontes "autorizadas" pelo Diário da Tarde para "contar" a realidade.

A escolha de tais fontes básicas, certamente, não acontece ao acaso; encontramos no jornal analisado, na maioria das vezes de maneira subliminar, alguns critérios que orientam este tipo de escolha do "testemunhal" e oferecem pistas sobre o "fazer-se" do periódico. Por vezes mencionando diretamente quais são as fontes consideradas fidedignas - por meio de expressões como "aquele que não tem por fim ocultar a verdade" ou ainda "homem de caráter cujo único objetivo é servir à nação", só para trazer alguns exemplos - ou tratando, conforme observamos, os grupos envolvidos no conflito com ênfases e enfoques diferenciados, o Diário da Tarde manifesta traços de um jeito próprio de fazer jornalismo, que é o que o diferencia dos demais periódicos existentes na capital paranaense e nos possibilita compreender por que as coisas foram ditas, construídas e interpretadas de tal maneira, e não de outra. Afinal, não se pode negar que são as falas do jornal e de suas fontes que constroem uma imagem específica do conflito em meio a diversas temáticas e jogos de sentido ao fazerem, efetivamente, que os sucessos e os fracassos das forças do exército e da polícia, os problemas sociais e as disputas políticas e econômicas "existam" e se insiram no ambiente social.

Para ilustrar esta observação podemos retomar dois momentos pontuais em que o jornal, talvez mais explicitamente que em outros momentos de sua rotina, informa sobre sua atuação no caso Contestado: a campanha de pacificação promovida em 1914 para evitar a atuação do governo federal na questão do Contestado e a mediação que estabelece em meio à política regional na definição dos limites entre os estados do Paraná e de Santa Catarina. 
A primeira, sem abrir mão de uma leitura estereotipada do sertanejo, o insere como vítima de sua própria ignorância e, por isso mesmo, merecedor de piedade de toda a nação. Opondo-se às atitudes mais hostis das forças do exército em relação aos sertanejos e trabalhando estrategicamente a formação de uma opinião pública sobre o assunto, o Diário da Tarde fez mais do que mostrar sua opinião - sua, ainda que firmada em adesões de indivíduos e segmentos sociais da capital. Mostrou, também, que havia um debate muito maior em torno da simples decisão de extermínio dos povos do Contestado para assegurar a paz. Guardadas as motivações que o fizeram agir deste modo neste momento específico, é preciso considerar que este tipo de atitude, que gerou manifestações da imprensa nacional e de relevantes grupos interessados e envolvidos na questão, só foi possível porque o jornal demarcou um campo de ação e, assim, entrou na disputa pela opinião e pelo próprio desfecho do conflito com "autoridade" para fazê-lo.

O segundo momento a que nos referimos diz respeito a um intenso debate que se estabelece na imprensa e em toda sociedade paranaense sobre a questão territorial, ou melhor, sobre a ameaça de perda das terras contestadas pelo estado do Paraná. Aqui, ao contrário do exemplo anterior, o Diário da Tarde não chega a assumir uma posição específica ao lado de um dos atores envolvidos na questão; o jornal, ao fazer política e pôr em cena poderes e forças, movimenta-se entre e sobre os rumos da decisão, chegando a contradizer perspectivas anteriormente referidas conforme o desfecho político da disputa. Neste momento, afirmações de um jornalismo imparcial - utilizadas como resposta aos demais periódicos que se manifestam sobre a disputa territorial ou grupos sociais direta ou indiretamente relacionados ao assunto em pauta - contribuem para definir o "lugar" que o periódico constrói para produzir sentido sobre os fatos do cotidiano, estabelecendo seu papel de porta-voz e agente das tensões e tendências de um contexto determinado.

Entretanto, em ambos os casos - e, certamente, em uma série de outras pautas e tratamentos discursivos do jornal - a justificativa de abordagem editorial apresentada ao público baseava-se no argumento de que era a missão do jornal, e do jornalista, informar e divulgar a "verdade" dos fatos e contribuir para o (re)estabelecimento da paz em tempos de conflito. Assim, as disputas pelo sentido travadas nas páginas do periódico, ao passo em que representam elementos de um fazer que dá ao Diário da 
Tarde um perfil singular de atuação e expressão, conformam-se em um olhar menos atento a simples "deveres" que compreendem as práticas cotidianas do jornalismo.

Levamos em conta, no entanto, que este tipo de interferência do jornal nos rumos dos acontecimentos significa muito mais do que um "dever" da profissão: constitui um modo de participar da construção da própria história, determinado pelo tipo de interação que o jornal estabelece com seu público, pela interferência que exerce na sociedade paranaense, pelo poder de dar existência pública a determinados eventos segundo certas práticas de seleção e apresentação retórica e, de modo geral, pela voz que faz ecoar e que lhe confere o papel de "testemunho" dos acontecimentos.

Também a aura de heroísmo que percorre os enunciados nos momentos em que o jornal trata episódios como o da morte de João Gualberto e de outros militares, as operações de guerra e os sucessos das forças oficiais constitui uma característica relevante para a identificação de um tipo de discurso ancorado em estruturações sociais já bastante cristalizadas. Neste contexto, é interessante analisar o modo pelo qual não apenas as vitórias, mas também as derrotas são expostas pelo jornal, de modo a revestir os insucessos de um caráter heróico e honroso. Construções discursivas que se filiam nesta direção vão tecendo, aos poucos, uma história de vencedores escrita pelo Diário da Tarde e aceita pelos seus leitores como verdadeira.

Importante observar que não procuramos aqui determinar, no percurso realizado pelo Diário da Tarde no caso Contestado, um posicionamento fixo e absolutamente coerente do periódico no tratamento do conflito sertanejo. Buscamos, antes, propor uma análise partindo da observação de sequências, rupturas e nuances que perpassam o atrelamento do jornal a certos setores sociais, a crítica ou oposição que elabora a pessoas e situações posicionadas em perspectivas diferentes, a busca e apuração das "verdades" dos fatos, a articulação de vozes e poderes em questões polêmicas, o debate público com demais órgãos de imprensa em torno de idéias e posições e ainda outros elementos não menos interessantes que foram apreendidos na análise dos processos mediáticos da Guerra do Contestado. Estas características, mesmo que tornem impossível uma leitura linear da fala do jornal no transcorrer da guerra, são responsáveis pela identificação de um "jeito de ser" exclusivo do produto estudado, na medida em que figuram como recursos utilizados para agir simbolicamente na construção dos acontecimentos. 
Olhando do início ao fim a presente pesquisa, podemos dizer que encontramos uma série de elementos que atuaram na produção de sentidos no período da Guerra do Contestado pelas falas do jornal paranaense. Ressaltamos, entre outras formulações possíveis, a oficialidade com que o conflito foi narrado e entrou para a história, a mudança relativa de orientação editorial segundo interesses e objetivos que variam conforme a situação em pauta e as manifestações de um jornalismo dito imparcial, plural e comprometido com a verdade (porém não apenas observador dos fatos) como traços de um dizer/fazer que nos mostra que cada discurso analisado só adquire e faz sentido por estar nas páginas do Diário da Tarde e envolver um universo maior da significação que não se revela em cada texto isoladamente.

Trata-se de um percurso que, ao se mover de acordo com os rumos e as decisões que envolvem a Guerra do Contestado e suas implicações, apresenta-se mais ou menos fiel às posições mais amplas e claramente definidas do jornal. Ao assumir diferentes posturas em momentos distintos do conflito sertanejo, por vezes negando e contradizendo falas anteriormente construídas, o periódico também faz revelar uma construção de sentidos articulada ao contexto em que atua, nem sempre de fácil apreensão nos relatos e estórias do cotidiano jornalístico.

Entre as temáticas aqui trabalhadas, percebemos a existência de questões essenciais e por isso mesmo nem sempre mencionadas explicitamente, ou na maioria das vezes enunciadas de forma pouco direta ou enviesada. É no interior desses intervalos, desses não-ditos, que se tornou possível depreender uma gama de representações sobre o movimento sertanejo e as questões da guerra que vai configurando, desdobrando e constituindo, no interior desse movimento, valores e significados sociais assumidos coletivamente. Ditos e não-ditos que pelo jornal ecoam, produzindo cotidianamente a história.

A relação entre as práticas de linguagem e as práticas históricas, ambas inseparáveis e em movimento, ultrapassa assim os limites do texto jornalístico para constituir a própria realidade social. O cotidiano e a história, apresentados de modo fragmentado nas diversas seções e páginas do jornal, ganham sentido ao serem conectados interdiscursivamente, ao percorreram a Guerra do Contestado em suas mais diversas expressões, pacíficas e/ou polêmicas. Aliás, é o próprio jogo de representações instaurado pelo jornal que permite mostrar que tantas vozes se fazem ouvir, 
constituindo um verdadeiro "coro polifônico" orquestrado por lógicas próprias.

Cada fragmento de jornal parece oferecer "pedaços" de significação, que se amoldam uns aos outros ou não, reafirmando-se ou negando-se, mas que de toda forma parecem construir uma espécie de jogo com múltiplas imagens. Esses jornais, que pareciam à primeira vista totalmente fragmentados e compostos por seções isoladas, ganharam no decorrer da análise outras características, já que no próprio periódico é possível captar os vários espaços que formam uma espécie de "todo difuso", contradizendo-se ou interligando-se em alguns momentos.

A identificação de algumas estratégias de criação da realidade que perpassam os discursos jornalísticos do Diário da Tarde permitiu encontrar questões e pistas das respostas que envolvem a imprensa no caso Contestado. Descartada a busca por uma "verdade histórica", procuramos investigar o percurso de construção da guerra na/pela imprensa por meio da observação dos contrastes entre as diversas falas, estabelecidas em meio à transação e transposição entre outras falas, de modo a considerar a dimensão comunicativa como uma arma para disputa de poderes, políticas e verdades, que ganha ressonância no tecido social.

Procuramos, do mesmo modo, analisar nos textos midiáticos a lógica interna e os laços que estabelecem com as relações sociais, suas condições históricas e formas de apresentação, seu funcionamento interno e o contexto social em que interagem. Listado deste modo, este tipo de análise "plural" pode ser considerado uma tarefa gigantesca (daí as eventuais lacunas que possa haver no processo de interpretação dos textos). Contudo, podemos argumentar que o desafio de realizar uma análise integrada dos elementos de sentido (fazendo prevalecer ora uma, ora outra perspectiva) tornou-se necessário e fundamental no estudo da relação entre história e comunicação. Neste sentido, consideramos os textos do jornal como "objeto" da análise, para além de serem os principais discursos públicos sobre os fatos; ou seja, os jornais não apenas como fontes capazes de informar sobre o contexto da época e a atuação de cada segmento da sociedade envolvido no conflito, mas também - e principalmente - como "elaboradores" da história por eles testemunhada.

Como os enunciados comportam, inevitavelmente, uma marca de tempo - representando, mais do que datas de um calendário, marcas de um discurso histórico -, manifestam sentidos latentes em meio à pluralidade 
de falas que, em determinado momento, tiveram a pretensão e o poder de dizer a "verdade". Percorrendo o modo como estas falas são inscritas pela ação discursiva do Diário da Tarde, a pesquisa considerou o Contestado como produto das estratégias e táticas utilizadas pelo jornal para "dizer" as verdades e os fatos, a fim de investigar nas representações sociais tecidas pela comunicação o papel do jornalismo na construção simbólica dos quatro anos de Guerra do Contestado.

Não nos furtamos a encerrar estas conclusões sem frisar que nem a pretensão diária de um jornalismo que quisesse mostrar o mundo de maneira imparcial, única e racional resistiria diante da constatação de que o jornal é um “campo polêmico". E, se assim o é, não dá para ignorar que o produto jornal resulta de uma infinita e imprevisível disputa de interesses que se deixa mostrar nas matérias, crônicas, editoriais e mesmo raras fotos e ilustrações que os periódicos do início do século XX traziam aos seus leitores. Um lugar de disputa, o produto jornal está distante de ser um lugar de consenso e manifestar um jeito único de pensar. O que não significa, como mostra a pesquisa sobre o Diário da Tarde no conflito Contestado, que não existam vozes e interpretações dominantes, que se sobrepõem às demais e assim encontram chão mais fértil para entrar para a história das gerações seguintes: conquistam espaço nos manuais escolares, honram os feitos oficiais e perpetuam alguns olhares enquanto apagam ou esquecem as outras vozes que existem mas não encontram eco junto aos leitores e demais atores sociais.

No conjunto de percepções resultante da pesquisa realizada, foi possível observar que o percurso percorrido pelo jornal para produzir a Guerra do Contestado é marcado por interferências do cenário político, econômico e cultural. A construção de imagens do sertanejo e dos militares, das derrotas e das vitórias e dos direitos do Paraná sobre o Contestado foi inegavelmente definida pela ação do Diário da Tarde, em diálogo com as forças sociais que nele obtiveram expressão e reconhecimento público. Isso permite dizer que os discursos produzidos pelo periódico serviram de suporte para uma "verdade histórica" que ganhou materialidade e repercutiu em suas páginas.

Por isso mesmo, a história da Guerra contada pelos jornais é muito mais do que a história de um conflito, com seus heróis e suas batalhas. É a história de uma guerra também simbólica constituída na articulação entre falas, contexto e fatos que "acontece" no Diário da Tarde, e não em 
outro jornal qualquer que circulava no mesmo período. Podemos, por isso mesmo, perceber como é poderoso o espaço discursivo do jornalismo; a seleção do evento, sua organização discursiva e a repercussão que assume na sociedade em que atua são mecanismos essenciais e indissociáveis da produção geral do significado, responsáveis, no caso estudado, por um modo singular de criar e entender a história.

O Contestado é um assunto nacional, que evoca memórias sobre um passado coletivo. Para a imprensa, embora possa eventualmente parecer apenas mais um entre tantos assuntos relevantes da sociedade da época, foi o resultado de um investimento de sentido que só foi possível no transcorrer do conflito devido à sua ação discursiva. Uma ação que fez do Contestado um acontecimento midiático produzido pelo Diário da Tarde.

Desse modo, lembrando que o esboço do conflito traçado nas páginas do jornal constitui uma maneira singular de "contar" este episódio ainda ignorado pela historiografia brasileira, quase um século depois, podemos tratar esta pesquisa como a busca por uma "imagem contestada". Como imagem, esta representação pode ser refletida e percebida de diferentes modos, por uma série de ângulos e impressões, pois se constrói, basicamente, pelos sentidos (movediços, polêmicos ou consensuais) produzidos e projetados pelo jornalismo.

Desta imagem - ou imagens - da Guerra do Contestado, tivemos aqui algumas pistas, demonstrações e contrastes que nos conduziram, no transcorrer da pesquisa, ao desafio de conhecer parte do trabalho de construção da realidade (histórica e social) pelos processos midiáticos, desvendando que papel é este atribuído ao jornalismo na discursivização da vida cotidiana. E, passados cem anos dos episódios que deram início ao movimento do Contestado, ainda é possível entender o lugar construído pela imprensa para contar a história, a partir do poder simbólico das palavras. 